\title{
Effects of Product Quality and Promotion on Purchase Decision: A Case Study of the Lanang Suhang Soluble Coffee in Lahat Regency
}

\author{
${ }^{1}$ Titi Hasanah, ${ }^{2}$ Hestin, ${ }^{3}$ Hardiyansyah \\ ${ }^{1,2,3}$ Sekolah Tinggi Ilmu Ekonomi Serelo Lahat, Indonesia
}

\begin{abstract}
This study aims to investigate the effects of product quality and promotion on purchase decisions. This analysis is a case study involving the Lanang Suhang soluble coffee brand in Talang Agung Village, Pajar Bulan District, Lahat Regency, South Sumatera, Indonesia. Data demonstrated that the soluble coffee brand has experienced growth of as much as $10 \%$ from the last 3 years of business operation. Data were collected through questionnaires and analysed using SPSS. Results reveal that product quality has no significant effects on purchase decisions. Conversely, the promotion has significant and positive effects on purchase decisions. Simultaneously, both product quality and promotion have significant and positive impacts on purchase decision of the Lanang Suhang soluble coffee brand located in the Talang Agung Village, Pajar Bulan District, Lahat Regency, South Sumatera, Indonesia. Practical implications are discussed.
\end{abstract}

Keywords: Product Quality, Promotion, Purchase Decision

\section{Introduction}

In this era of technological developments and the Covid-19 pandemic, home industry businesses proliferate. One of them is the soluble coffee business. The majority of residents in Lahat involve in this home industry. Despite this, ample businesses neglect the factors of product quality and promotion. Product quality and promotion are two of the primary factors driving consumers' buying decisions. Failing to pay attention to these two elements will lower the efficacy of marketing efforts. Businesses need to have their own advantages for consumers so that they can maintain existing market share. One of the fastest-growing businesses at this time is soluble coffee. The contributing factor of this is the Covid-19 pandemic, where people mainly limit their mobility and stay at home and perform activities online. The problem soluble coffee businesses encounter is sales promotion. For example, the internet signal in the village is lacking and access to the place is far. These issues cause consumers to restrain themselves from purchasing the soluble coffee offered by businesses.

Quality improvement is one of the marketing strategies that emphasise meeting customers' needs and wants. To enhance quality, a business must offer products that can be accepted according to what customers expect. Businesses offering soluble coffee in the Talang Pagar Agung Village promote their brands through brochures, radio broadcasts, social media (e.g., WhatsApp, Facebook, and Instagram), and other media. In addition, to attract customers, the businesses enhance their products' taste, aroma, and packaging. The case study within this research has experienced $10 \%$ growth from 2018 to 2020 . The improvement occurred due to the brand's effort in selling its soluble coffee through various channels such as small stalls, tourist attraction shops near Mount Dempo, and online sales.

Due to the competitive nature of the soluble coffee sector within the local market, the case study should consider the product quality and promotion in its marketing blueprint. This endeavour will significantly influence consumers' purchasing decisions concerning soluble coffee.

\section{Research Methods \\ Population and sample}


The population within this research was unknown. Therefore, in determining the total sample, this research multiplied the count of the variable by 10 to 20 . As a result, the calculation was $3 \times 10$, generating a total of respondents of 30 . The sampling technique was accidental sampling.

\section{Data source}

This research obtained data from two sources. They were primary and secondary sources.

\section{Types of research}

The type of research used in this study was quantitative research with a descriptive approach. Quantitative research methods are one type of research whose specifications are systematic, planned and structured, used to examine specific populations or samples.

\section{Data analysis method}

This study analysed the data utilising SPSS (Statistical Package for Social Science). There were several data analysis techniques used in this study, namely research instrument test, validity test, reliability test, classical assumption instrument test, normality test, multicollinearity test, heteroscedasticity test, multiple regression test, the goodness of fit test, t-test, f-test, correlation coefficient and coefficient of determination.

\section{Analysis and Discussion Results \\ Description of Respondent Data}

1. Characteristics of Respondents by Gender

Table 1. Characteristics of Respondents by Gender

\begin{tabular}{|l|l|l|}
\hline Gender & Total respondent & Percentage \\
\hline Female & 12 & $38 \%$ \\
\hline Male & 18 & $62 \%$ \\
\hline Total & 30 & $100 \%$ \\
\hline
\end{tabular}

Based on Table 1, the predominant respondents (62\%) were male, with 12 people. The remaining 12 respondents were female, with a percentage of $38 \%$. This demonstrated that the majority of consumers were male regarding the propensity in purchasing the soluble coffee brand of Lanang Suhang in Talang Pagar Agung Village, Pajar Bulan District, Lahat Regency.

2. Characteristics of respondents by age level

Table 2. Characteristics of Respondents Based on Age

\begin{tabular}{|l|l|l|}
\hline Age (years old) & Total respondent & Percentage \\
\hline$<20$ & 1 & $5 \%$ \\
\hline $21-30$ & 7 & $20 \%$ \\
\hline $31-40$ & 10 & $40 \%$ \\
\hline $41-50$ & 8 & $25 \%$ \\
\hline$>50$ & 4 & $10 \%$ \\
\hline Total & 30 & $100 \%$ \\
\hline
\end{tabular}

Based on the table above, it is apparent that the respondents who visited the Lanang Suhang soluble coffee brand, Talang Pagar Agung Village, were dominated by adults at the age level of 31-40 years, which amounted to 10 respondents with a percentage of $40 \%$ in the field survey. Next, the respondents had an age level between 21-30 years, which was 7 people with a percentage of 20\%. The third-largest respondent was between 41-50 years old, which was 8 respondents with a percentage of $20 \%$ and over 50 years old. There 
were 4 respondents with a percentage of $10 \%$, while 1 other respondent under 20 years old had the lowest percentage of $5 \%$

3. Characteristics of respondents based on the level of work

Table 3. Characteristics of Respondents Based on Employment Level

\begin{tabular}{|l|l|l|}
\hline Occupation & Total respondent & Percentage \\
\hline Pelajar/mahasiswa & 1 & $10 \%$ \\
\hline Pegawai swasta & 8 & $20 \%$ \\
\hline PNS & 5 & $15 \%$ \\
\hline Tidak bekerja & 5 & $15 \%$ \\
\hline Wiraswasta & 11 & $40 \%$ \\
\hline Total & 30 & $100 \%$ \\
\hline
\end{tabular}

According to Table 3, the respondents who chose coffee powder the most were those who had jobs as entrepreneurs, namely 11 people with a percentage of $40 \%$, while the response of private employees was 8 people with a percentage of $20 \%$. Unemployed respondents were 5 people with a percentage of $15 \%$. Civil servants were 5 people with a percentage of $15 \%$. The lowest number was 1 person with a percentage of $10 \%$ of the respondents was a student.

4. Characteristics of respondents based on the education level

Table 4. Characteristics of Respondents Based on Education

\begin{tabular}{|l|l|l|}
\hline Education & Total respondent & Percentage \\
\hline Junior high school & 7 & $20 \%$ \\
\hline Senior high school & 11 & $40 \%$ \\
\hline Diploma & 2 & $5 \%$ \\
\hline Bachelor & 7 & $20 \%$ \\
\hline Master & 3 & $15 \%$ \\
\hline Total & 30 & $100 \%$ \\
\hline
\end{tabular}

In Table 4, it is evident that respondents who visited the Lanang Suhang soluble coffee brand in Talang Paggar Agung village were dominated by high school education, which was in the percentage level of $40 \%$, totalling 11 people with high school education. The percentage of $20 \%$ was 7 people with junior high school education. There were 7 people with a bachelor degree. The percentage of $15 \%$ amounted to 3 people with a master degree while the minimum percentage of Diploma education was 2 people with a percentage of $5 \%$.

\section{Frequency Distribution}

1. Frequency distribution of product quality

Table 4. Product quality frequency distribution

\begin{tabular}{|l|l|l|l|l|l|}
\hline No & Statement & \multicolumn{3}{l|}{ Scale } \\
\hline Quality & Mean & $\begin{array}{l}\text { TCR } \\
(\%)\end{array}$ & N & Category \\
\hline Performance & & & & \\
\hline 1 & $\begin{array}{l}\text { Kopilanang Suhang's soluble coffee } \\
\text { brand can compete with other soluble }\end{array}$ & 3,83 & 76,66 & 30 & Moderate \\
\hline
\end{tabular}




\begin{tabular}{|c|c|c|c|c|c|}
\hline & $\begin{array}{l}\text { coffee brands to sell coffee powder } \\
\text { products }\end{array}$ & & & & \\
\hline 2 & $\begin{array}{l}\text { Environmental hygiene and equipment } \\
\text { in the processing of coffee powder is } \\
\text { paramount } \\
\text { The price of coffee powder products is } \\
\text { sold at prices below competitors' prices }\end{array}$ & 3,90 & 78 & 30 & Moderate \\
\hline \multicolumn{6}{|c|}{ Durability } \\
\hline 4 & $\begin{array}{l}\text { Prioritising consumer opinions on } \\
\text { product quality }\end{array}$ & 4,03 & 80,66 & 30 & Good \\
\hline 5 & $\begin{array}{l}\text { The durability of coffee powder } \\
\text { products is prioritised }\end{array}$ & 4,03 & 80,66 & 30 & Good \\
\hline \multicolumn{6}{|c|}{ Packaging } \\
\hline 6 & $\begin{array}{l}\text { The quality of the essential ingredients } \\
\text { of coffee powder uses good quality, for } \\
\text { example, coffee beans that are } \\
\text { adequately prepared (picked when it is } \\
\text { red) }\end{array}$ & 4,03 & 80,66 & 30 & Good \\
\hline 7 & $\begin{array}{l}\text { Lanang Suhang coffee powder product } \\
\text { packaging appearance can attract } \\
\text { buyers }\end{array}$ & 4,10 & 82 & 30 & Good \\
\hline 8 & $\begin{array}{l}\text { The colour and aroma of Lanang } \\
\text { Suhang coffee grounds attract buyers }\end{array}$ & 4,06 & 81,33 & 30 & Good \\
\hline 9 & $\begin{array}{l}\text { The shape of the packaging product is } \\
\text { convincing with the size and content of } \\
\text { the packaging }\end{array}$ & 4,00 & 80 & 30 & Good \\
\hline 10 & $\begin{array}{l}\text { Lanang Suhang coffee powder has an } \\
\text { attractive product design }\end{array}$ & 4,03 & 80.66 & 30 & Good \\
\hline \multicolumn{2}{|c|}{ Average of Quality } & 3,99 & 79,86 & 30 & Moderate \\
\hline
\end{tabular}

From the results of this analysis, it is evident that the average quality score in the Lanang Suhang soluble coffee brand was Good because the average score was 3.99 in a score range of 1 to 3 . It is also discernable that the TCR value was $79.86 \%$ which included in the very good category.

2. Promotion frequency distribution

Table 5. Promotion frequency distribution

\begin{tabular}{|l|l|l|l|l|l|}
\hline No & Pernyataan & \multicolumn{3}{l|}{ Skala } \\
\hline Promotion & Mean & $\begin{array}{l}\text { TCR } \\
(\%)\end{array}$ & N & Category \\
\hline Promotion quality & & & & \\
\hline 1 & $\begin{array}{l}\text { In the advertisement promotion, it } \\
\text { provides an overview of how to process } \\
\text { Lanang Suhang coffee powder }\end{array}$ & 3,66 & 73,33 & 30 & Moderate \\
\hline
\end{tabular}






From the results of this analysis, the average Promotion score in the Lanang Suhang soluble coffee brand was fairly good because the average score was 3.92 in a score range of 1 to 4 . It is also apparent that the TCR value was $79.2 \%$. included in the category of Moderate.

\section{Test Instrument}

1. Validity Test

Table 7. Validity Test Results

\begin{tabular}{|l|l|l|l|l|}
\hline Variable & Instrument & r-value & r-table & Conclusion \\
\hline Product quality (X1) & $\mathrm{P} 1$ & 0,864 & & Valid \\
\cline { 2 - 3 } & $\mathrm{P} 2$ & 0,731 & & Valid \\
\cline { 2 - 3 } & & & & \\
\hline
\end{tabular}




\begin{tabular}{|c|c|c|c|c|}
\hline & $\mathrm{P} 3$ & 0,647 & \multirow{8}{*}{0,361} & Valid \\
\hline & $\mathrm{P} 4$ & 0,651 & & Valid \\
\hline & $\overline{\mathrm{P} 5}$ & 0,750 & & Valid \\
\hline & P6 & 0,823 & & Valid \\
\hline & $\mathrm{P7}$ & 0,820 & & Valid \\
\hline & P8 & 0,697 & & Valid \\
\hline & P9 & 0,709 & & Valid \\
\hline & $\mathrm{P} 10$ & 0,789 & & Valid \\
\hline Promotion (X2) & $\mathrm{P} 1$ & 0,886 & & Valid \\
\hline & $\mathrm{P} 2$ & 0,788 & & Valid \\
\hline & $\mathrm{P} 3$ & 0,824 & & Valid \\
\hline & $\mathrm{P} 4$ & 0,724 & & Valid \\
\hline & $\mathrm{P5}$ & 0,863 & & Valid \\
\hline & P6 & 0,601 & 0,361 & Valid \\
\hline & P7 & 0,795 & & Valid \\
\hline & $\mathrm{P} 8$ & 0,785 & & Valid \\
\hline & P9 & 0,825 & & Valid \\
\hline & P10 & 0,730 & & Valid \\
\hline Purchase decision $P$ & P1 & 0,845 & & Valid \\
\hline (Y) & P2 & 0,846 & & Valid \\
\hline & P3 & 0,781 & & Valid \\
\hline & $\mathrm{P} 4$ & 0,712 & & Valid \\
\hline & $\mathrm{P5}$ & 0,786 & & Valid \\
\hline & P6 & 0,605 & 0,361 & Valid \\
\hline & P7 & 0,802 & & Valid \\
\hline & P8 & 0,771 & & Valid \\
\hline & P9 & 0,772 & & Valid \\
\hline & P10 & 0,805 & & Valid \\
\hline
\end{tabular}

Based on table 7 above, the validity test results, all the question items in the questionnaire in this study were declared valid, meaning that each statement in the questionnaire had a level of accuracy in measuring product quality, promotion, and purchase decisions variables where the value of $r$ table for the sample at a significant level of $5 \%$ is 0.361 , where the value is $>0.361$ ( $\mathrm{r}$ table).

2. Reliability Test

Table 8. Reliability Test Results

\begin{tabular}{|l|l|l|l|}
\hline Variable & $\begin{array}{l}\text { Cronbach's } \\
\text { Alpha }\end{array}$ & $\begin{array}{l}\text { Lower } \\
\text { Limit } \\
\text { Value }\end{array}$ & Status \\
\hline Product quality $(\mathrm{X} 1)$ & 0,910 & 0,600 & Reliab \\
\hline
\end{tabular}




\begin{tabular}{|l|l|l|l|}
\hline Promotion (X2) & 0,928 & 0,600 & le \\
Purchase Decision (Y) & 0,923 & 0,600 & Reliable \\
& & & Reliable \\
\hline
\end{tabular}

The table above exhibits that the value of Cronbach's alpha of the product quality variable (X1) and the promotion variable $(\mathrm{X} 2)$ on the purchasing decision variable (Y) obtained was greater than 0.600. Accordingly, the instruments for the three variables were reliable.

\section{Classic assumption test}

1. Normality Test

Table 9. Normality Test Results

\begin{tabular}{|l|l|l|}
\hline \multicolumn{2}{|l|}{ One-Sample Kolmogorov-Smirnov Test } \\
\hline \multicolumn{2}{|l|}{} & $\begin{array}{l}\text { Unstandardis } \\
\text { ed Residual }\end{array}$ \\
\hline N & 30 \\
\hline Normal Parameters, & Mean & .0000000 \\
\cline { 2 - 3 } & $\begin{array}{l}\text { Std. } \\
\text { Deviation }\end{array}$ & 2.63304886 \\
\hline $\begin{array}{l}\text { Most Extreme } \\
\text { Differences }\end{array}$ & Absolute & .132 \\
\cline { 2 - 3 } & Positive & .132 \\
\cline { 2 - 3 } & Negative & -.099 \\
\hline Test Statistic & .132 \\
\hline Asymp. Sig. (2-tailed) & $.193^{\mathrm{c}}$ \\
\hline a. Test distribution is Normal. \\
\hline b. Calculated from data. \\
\hline c. Lilliefors Significance Correction. \\
\hline
\end{tabular}

Based on table 9, by comparing the p-value obtained with a significant level of $5 \%$, the data is normally distributed if the $p$ value $>0.05$. The probability value (p) shows a number of 0.193 with a significant level of 0.05 . Thus, the data is normally distributed because $p>0.05$. Normally distributed data was a prerequisite for the use of parametric statistics.

Figure 4 Normality Probability Plot

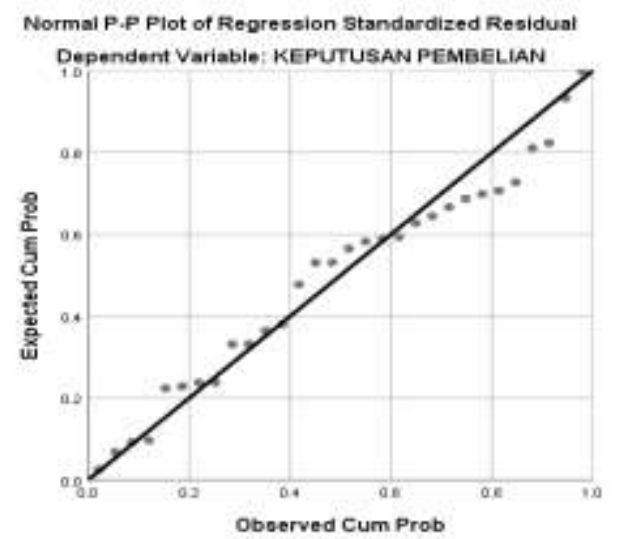


Based on the graph above, the purchase decision at the Lanang Suhang Soluble coffee brand, Talang Pagar Agung Village, Pajar Bulan District, Lahat Regency. Normally distributed and can be used in research because the points in the image follow a slanted line, spread out and do not overlap in one place.

2. Multicollinearity Test

Table 10. Multicollinearity Test Results

\begin{tabular}{|l|l|l|l|}
\hline Variable & Tolerance & VIF & Description \\
\hline Quality & 0,138 & 7,242 & There is no multicollinearity \\
Promotion & 0,138 & 7,242 & There is no multicollinearity \\
\hline
\end{tabular}

Table 10. The results of the multicollinearity test (product quality and promotion variables) do not have a VIF greater than 10 . Hence, the multicollinearity problem within regression data was absent.

3. Heteroscedasticity Test

Table 11. Heteroscedasticity Test Results

\begin{tabular}{|l|c|l|l|l|l|}
\hline Variable & $\mathbf{t}_{\text {value }}$ & $\mathbf{t}$ table & $\mathbf{p}$-value & Sig. & Conclusion \\
\hline $\begin{array}{l}\text { Quality } \\
\text { Promotion }\end{array}$ & $-0,811$ & 2,079 & 0,424 & $\mathrm{p}>0,05$ & $\begin{array}{l}\text { There is no heteroscedasticity } \\
\text { There is no heteroscedasticity }\end{array}$ \\
\hline
\end{tabular}

Based on the results of the heteroscedasticity test using the Glejser method, it turns out that in the model, there is no problem. It is evident from the significance value of service quality $(0.424)>0.05$ while the promotion value of sig $(0.560)>0.05$. Because the $\mathrm{p}$-value/sig value is greater than 0.05 , the heteroscedasticity within each variable was absent.

Multiple Linear Regression Test

Table 12 Regression Coefficient Results

\begin{tabular}{|c|c|c|c|c|c|}
\hline \multicolumn{6}{|l|}{ Coefficients } \\
\hline \multirow[b]{2}{*}{ Model } & \multicolumn{2}{|c|}{$\begin{array}{l}\text { Unstandardised } \\
\text { Coefficients }\end{array}$} & \multirow{2}{*}{\begin{tabular}{|l|}
$\begin{array}{l}\text { Standardised } \\
\text { Coefficients }\end{array}$ \\
Beta
\end{tabular}} & \multirow[b]{2}{*}{$\mathrm{T}$} & \multirow[b]{2}{*}{ Sig. } \\
\hline & B & Std. Error & & & \\
\hline (Constant) & 7.331 & 3.506 & & 2.091 & .046 \\
\hline Product quality & -.039 & .234 & -.038 & -.165 & .870 \\
\hline Promotion quality & .879 & .220 & .929 & 4.005 & .000 \\
\hline
\end{tabular}

Based on the results of data analysis as presented in table 12. above, the regression equation obtained is: $Y=7.331-0.039 X_{1}+0,879 X_{2}$

It means that if there is no quality variable (X1) and Promotion (X2), then it has a purchasing decision of 1.736

1. The coefficient value of 7.331 indicates that with the quality (X1) and Promotion (X2), the magnitude of the purchase decision is 7.331 
2. The coefficient value is -0.039 , the sign (-) indicates the relationship between product quality and purchasing decisions is negative, or if the quality variable (X1) is increased by one unit while the Promotion variable (X2) is constant, the purchase decision will not increase by 0.849

3 . The coefficient value is +0.879 , the sign ( + ) indicates the relationship between promotion and purchasing decisions is positive, or if the promotion variable (X2) is increased by one unit while the quality variable (X1) is constant, the purchasing decision will increase by 0.879 .

\section{Goodness Of Fit Test}

T Uji test

(1) Testing the effect of the quality variable (X1) on purchasing decisions in the Lanang Suahang soluble coffee brand in the village of Talang Pagar Agung

$\mathrm{HO}:=0$ (there is no effect between product quality variables (X1) and purchasing decisions (Y) )

$\mathrm{H} 1:>0$ (there is an influence between product quality variables (X1) and purchasing decisions (Y))

$\mathrm{T}$ table $=\mathrm{t}(\mathrm{a} / 2: \mathrm{n}-\mathrm{k}-1)$

$\mathrm{T}$ table $=\mathrm{t}(\mathrm{a} / 2: \mathrm{n}-\mathrm{k}-1)$

$\mathrm{a}=5 \%=30-2-1=27$

$=0.025 ; 27$

$=2.079$

Thus, it can be said that the influence of product quality (X1) on purchasing decisions (Y) with a $95 \%$ confidence level $(=0.05)$, obtained $\mathrm{t}$ count $(-0.165)<\mathrm{t}$ table $(2.079)$, then HO is accepted and H1 rejected, then partially product quality (X1) has no positive and insignificant effect on purchasing decisions in the Lanang Suhang soluble coffee brand.

(2). Testing the effect of the Promotion variable (X2) on purchasing decisions (Y) in the Lanang Suhang soluble coffee brand

$\mathrm{HO}:=0$ (no influence on store image and purchasing decisions)

$\mathrm{H} 1:>0$ (there is an effect of store image and purchasing decisions)

$\mathrm{T}$ table $=\mathrm{t}(\mathrm{a} / 2: \mathrm{n}-\mathrm{k}-1)$

$\mathrm{T}$ table $=\mathrm{t}(\mathrm{a} / 2: \mathrm{n}-\mathrm{k}-1)$

$\mathrm{a}=5 \%=30-2-1=27$

$=0.025 ; 27$

$=2.079$

Thus, it shows that the influence of store image on purchasing decisions (Y) with a $95 \%$ confidence level (= 0.05), obtained t count (4.005) > t table (2.079), then HO is accepted, and $\mathrm{H} 1$ is rejected, then automatically partial promotion (X2) has a positive and significant effect on purchasing decisions.

Lanang Suhang Soluble coffee brand, Talang Pagar Agung Village, Pajar Bulan District, Lahat Regency

2. F test

Table 13. Analysis of Variance

\begin{tabular}{|l|l|l|l|l|l|l|}
\hline \multicolumn{2}{|l|}{ ANOVA } \\
\multicolumn{2}{|l|}{ Model } & $\begin{array}{l}\text { Sum } \\
\text { Squares }\end{array}$ & df & Mean Square & F & Sig. \\
\hline \multirow{2}{*}{1} & Regression & 800.145 & 2 & 400.072 & 53.726 & $.000^{\mathrm{b}}$ \\
\cline { 2 - 8 } & Residual & 201.055 & 27 & 7.446 & & \\
\hline
\end{tabular}




\begin{tabular}{|l|l|l|l|l|}
\hline Total & 1001.200 & 29 & & \\
\hline \\
a. Dependent Variable: Purchase decision \\
\hline \\
b. Predictors: (Constant), promotion quality, product quality \\
\hline
\end{tabular}

Determine the level of significance (lalpha ), which is $5 \%$.

Df $1=3-1=2$

Df $2=30-2-1=27$

$\mathrm{Df}=3.35$

Tests to see the effect of quality and promotion variables on purchasing decisions of Lanang Suhang Soluble coffee brand, Talang Pagar Agung Village, Pajar Bulan District, Lahat Regency, resulted in Fcount 53.726 and Ftable 3.35 and a significant level value of $\mathrm{F}=0.000$ (P-value) $<$ ). Based on these results, the decision is to reject $\mathrm{HO}$ and accept $\mathrm{H} 1$. So the variables of quality and promotion simultaneously have a significant effect on purchasing decisions at the Lanang Suhang Soluble coffee brand, Talang Pagar Agung Village, Pajar Bulan District, Lahat Regency.

3. Correlation Coefficient and Determination Coefficient

Table 14. Correlation Coefficient (R) and Determination Coefficient (R2)

\begin{tabular}{|l|l|l|l|l|}
\hline \multicolumn{2}{|l|}{ Model Summary } \\
\hline Model & R & R Square & $\begin{array}{l}\text { Adjusted R } \\
\text { Square }\end{array}$ & $\begin{array}{l}\text { Std. Error of } \\
\text { the Estimate }\end{array}$ \\
\hline 1 & $.894^{\text {a }}$ & .799 & .784 & 2.72883 \\
\hline a. Predictors: (Constant), promotion, product quality \\
\hline
\end{tabular}

The results of multiple regression analysis get a multiple correlation coefficient (r) of 0.894 . This confirms that product quality and promotion have a strong relationship with purchasing decisions at the Lanang Suhang Soluble coffee brand, Talang Pagar Agung Village, Pajar Bulan District, Lahat Regency. The magnitude of the coefficient of determination (R2) is 0.799 . This means that changes in the variation of purchasing decisions at Lesehan Pondok Mio Lahat can be explained by product quality variables (X1) and promotions (X2) with a contribution of $79.9 \%$. In comparison, the remaining $20.1 \%$ can be explained by other variables not included in this model.

\section{Discussion}

\section{Effect of product quality on purchasing decisions}

Partial (individual) testing to determine whether there is an effect of product quality on purchasing decisions is in Table 12. The t-count value on product quality $(-0.165)$ is smaller than the $t$-table value of 2.079 (or significance value $>0.05$ ). The partial test (individual) shows that product quality has no positive and insignificant effect on purchasing decisions at the Lanang Suhang Soluble coffee brand, Talang Pagar Agung Village, Pajar Bulan District, Lahat Regency. The results of this study support research conducted by Dita and Syahputra (2017), which states that in a partial test (individual), store atmosphere has a positive and significant effect on purchasing decisions at Coffee Shops in Bandung. 
Partial (individual) testing to determine whether store image influences purchasing decisions is influenced by Table 12. The t-count value on promotion $(4,005)$ is greater than the t-table value of 2,079 (or significance value $<0.05$ ), meaning that the Partial test (individual) shows that promotion has a positive and significant effect on purchasing decisions at the Lanang Suhang Soluble coffee brand, Talang Pagar Agung Village, Pajar Bulan District, Lahat Regency. This means that there is a significant relationship between promotions and purchasing decisions.??????? Many studies have found the opposite result. Namely, store image has a significant effect on purchasing decisions (Kemal, 2018). However, this does not apply to this discussion. One of the factors is that the services provided by consumers are not following their wishes. The results of this study support the research conducted by Cindy \& Rudy (2015), which states that brand image has an insignificant effect on Purchase Decisions at Time Out Sports Cafe IT Center Manado.

\section{Effect of product quality and promotion on purchasing decisions}

Simultaneous testing (simultaneously) to determine whether product quality and promotion affect purchasing decisions at the Lanang Suhang Soluble coffee brand, Talang Pagar Agung Village, Pajar Bulan District Lahat Regency, can be seen in Table 13. Both variables simultaneously have a positive and significant effect on purchasing decisions. This is apparent in the Fcount 53.726 and Ftable 3.35 and the significant level value $\mathrm{F}=0.000$ (Pvalue $<$ ), which means purchasing decisions will increase if the product quality is good and promotions can attract consumers. The results of this study support the research conducted by Maretha and Engkos (2011), which states that Store Atmosphere and Store Image have a significant influence on Consumer Purchase Decisions in the Lanang Suhang soluble coffee brand in Talang Pagar Agung Village, Pajar Bulan District, Lahat Regency.

\section{Conclusions and Suggestions \\ Conclusion}

Based on the results of the analysis and discussion, the authors conclude: that (1) partially the t-count value on product quality $(-0.165)$ is smaller than the t-table value, namely 2.079 (or significance value $>0.05$ ), meaning that the partial test ( individual) shows that product quality does not have a positive and insignificant effect on purchasing decisions at the Lanang Suhang Soluble coffee brand, Talang Pagar Agung Village, Pajar Bulan District, Lahat Regency (2) partially the t-count value on promotion $(4,005)$ is greater than The t-table value is 2.079 (or significance value $<0.05$ ) meaning that the partial test (individual) shows that promotion has a positive and significant effect on purchasing decisions at the Lanang Suhang Soluble coffee brand, Talang Pagar Agung Village, Pajar Bulan District, Lahat Regency. (3) Simultaneously, the Fcount value is 53.726 and Ftable 3.35 and the significant level value $\mathrm{F}=0.000$ (Pvalue $<$ ) has an effect positive and significant impact on purchasing decisions in the Lanang Suhang powder business, Pajar Bulan sub-district, Lahat district.

\section{Suggestion}

Based on the results of the study and the conclusions obtained, the suggestions that can be submitted are as follows:

1. Promotion is a problem that needs attention in opening a Lanang Suhang soluble coffee brand, Talang Pagar Agung village, Pajar Bulan sub-district. Most consumers buy Lanang Suhang coffee powder because the quality of their coffee products uses selected coffee. Therefore the management is expected to maintain product quality-furthermore, sales promotions contained in the Lanang Suahang soluble coffee brand, Lahat district, Lahat district.

2. This research expects that the results of this study can be beneficial as reference material for further researchers who research with the same concept. In future research, researchers will use different variables from the variables used in this study to obtain more varied results from the influence of store atmosphere, store image, and purchasing decisions.

\section{References}


1. Irma Rosmayati,Hani Siti Hanifah and Adil Fajri Badiman.2020. Effects of Promotion and Service Quality on Purchase Decision of Kopi Mahkota Java Coffe Garut. Jurnal Wacana Ekonomi.Desember 19(3):h: 186-191 (Translated from Indonesian).

2. Kumambong, R. H., Mandey, S., \& Wenas, R. (2017). Analysis of the Influence of Psychology Factors, Product Quality, and Promotion on Purchase Decision of Shop Establishments at PT Wenang Permai Sentosa. Jurnal EMBA: Jurnal Riset Ekonomi, Manajemen, Bisnis dan Akuntansi, 5(2). ;h: 802-810 (Translated from Indonesian).

3. Mulyana, T. (2016). Effects of Service Quality and Promotion on Purchase Decision of Yamaha Motorcycle at PT Astra Garut. Jurnal Wacana Ekonomi, 15(2), 033-040. (Translated from Indonesian).

4. Permana, D. I. (2017). The Effect of Promotion on Purchase Decision of Wooden Flooring Products and Doors at PT Piji in Jawa Timur. Jurnal Manajemen dan Start-Up Bisnis, 2(1), 117-123. (Translated from Indonesian).

5. Rumondor, P. W., Tumbel, A. L., \& Ogi, I. W. (2017). Effects of Product Quality, Price, and Word of Mouth on Purchase Decision of Rumah Kopi and Mie Toronata in Kawangkoan. Jurnal EMBA: Jurnal Riset Ekonomi, Manajemen, Bisnis dan Akuntansi, 5(2). h;1102-1112 (Translated from Indonesian).

6. Walukow, A. L. P., \& Mananeke, L. (2014). Effects of Product Quality, Price, Promotion, and Location on Purchase Decision in Bentenan Center Sonder Minahasa. Jurnal EMBA: Jurnal Riset Ekonomi, Manajemen, Bisnis dan Akuntansi, 2(3). :h:1737-1749 (Translated from Indonesian).

7. Weenas, J. R. (2013). Effects of Product Quality, Price, Promotion, and Service Quality on Purchase Decision of Spring Bed Comforta. Jurnal EMBA: Jurnal Riset Ekonomi, Manajemen, Bisnis dan Akuntansi, 1(4). (Translated from Indonesian). 